\title{
Correction to: Area of protection in S-LCA: human well-being or societal quality
}

\author{
Yazdan Soltanpour ${ }^{1,2}(1) \cdot$ Iuri Peri $^{1} \cdot$ Leilla Temri $^{2}$
}

Published online: 27 May 2019

(C) Springer-Verlag GmbH Germany, part of Springer Nature 2019

\section{Correction to: Int J Life Cycle Assess} https://doi.org/10.1007/s11367-019-01620-y

The original version of this article unfortunately contained a mistake.

The spelling of the first author's name is "Yazdan Soltanpour".

The original article has been corrected.

Publisher's note Springer Nature remains neutral with regard to jurisdictional claims in published maps and institutional affiliations.

The online version of the original article can be found at https://doi.org/ 10.1007/s11367-019-01620-y

Yazdan Soltanpour

yazdan.soltanpour@supagro.fr

1 Department of Agriculture, Food and Environment, University of Catania, Catania, Italy

2 MOISA, Montpellier SupAgro, CIRAD, CIHEAM-IAMM, INRA, Univ Montpellier, Montpellier, France 